\title{
Результаты испытаний элементов мостовых сооружений из стеклопластика после 12 лет эксплуатации
}

\section{Testing results of bridge fiberglass elements after 12 years of exploitation}

\author{
А. Е. Ушаков, А. В. Панков, А. А. Сафонов, С. Н. Озеров, \\ Т. Г. Сорина, А. С. Цветков, А. Е. Муравьев, \\ М. А. Хруленко, Ю. Г. Кленин \\ ООО «Научно-технологический испытательный центр \\ «АпАТэК-Дубна», Россия, г. Дубна
}

Поступила в редакцию 23.07.2021, принята к печати 03.09.2021

\author{
A. E. Ushakov, A. V. Pankov, A. A. Safonov, S. N. Ozerov, \\ T. G. Sorina, D. S. Tsvetkov, A. E. Muraviov, \\ M. A. Khrulenko, Y. G. Klenin
}

Scientific and technological testing center ApATeCh-Dubna" LLC, Russia, Dubna

\section{Абстракт}

Надёжность конструкции пешеходных мостов, изготовленных из пултрузионного стеклопластика «АпАТэК СППС», подтверждена испытаниями распорки пилона, демонтированной для исследований с вантового моста из стеклопластиковых профилей, установленного в Дубне и эксплуатирующегося с 2005 г. по настоящее время. Сделан вывод о безопасности дальнейшей эксплуатации на основании стабильности упруго-прочностных характеристик при совместном долговременном воздействии климатических и эксплуатационных факторов.

\section{Abstract}

Structural reliability of the footbridges made from a pultrusion glass fiber reinforced material "ApATeCh SPPS" is verified by testing a pylon strut removed for the analysis from the cable bridge made of fiberglass profiles, which has being in operation since 2005 in Dubna. A conclusion is drawn that further operation of the bridge is safe since stability of the elastic and strength characteristics under the combined long-term exposure of the environmental and operational factors is revealed.

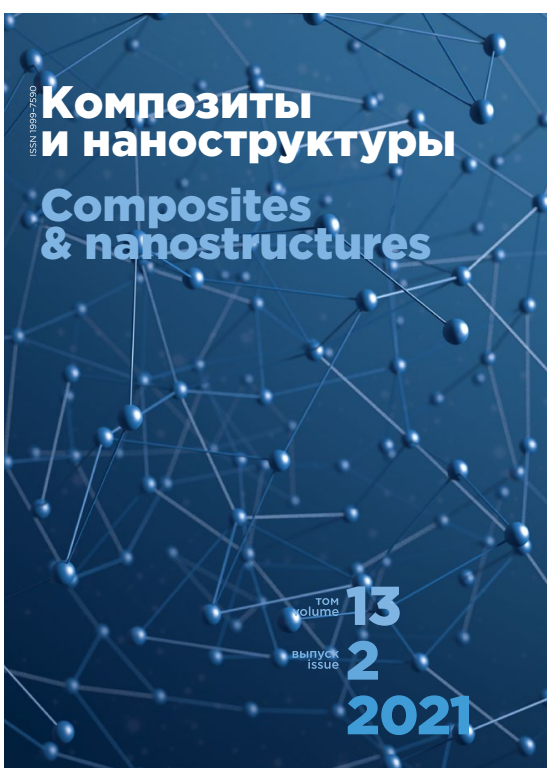

